


\section{A 'semio' approach to fashion discourse: critical perspectives on the luxury industry}

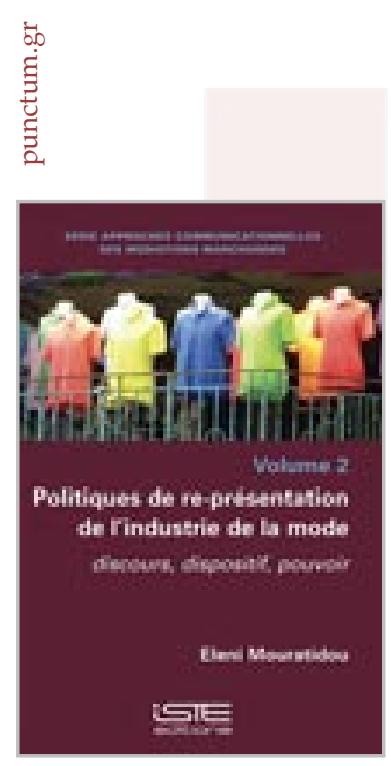

ARTICLE INFO:

Volume: 06

Issue: 02:2020

Month: March

ISSN: 2459-2943

DOI: 10.18680/hss.2020.0031

Pages: 249-252

By: François Provenzano

LiC.: CC BY-NC-ND 4.0
BY: François Provenzano

Eleni Mouratidou, 2020

Politiques de re-présentation de l'industrie de la mode. Discours, dispositif, pouvoir

London, ISTE Editions Ltd, 2020, ISBN 978-1-78405-678-0 (print)

ISBN 978-1-78406-678-9 (e-book), 206 p.

$\square$ his book offers rich and clear critical perspectives on the

1 luxury fashion industry and its market mediations. It relies on a multi-layered methodology and deals with a wide variety of materials: texts, images, but also objects, experiences, exhibitions, buildings, interiors. By doing so, Mouratidou demonstrates the unity (in other words: the standard format) of the politics of re-presentation in the luxury fashion industry and the unity of the semio approach she defends. Grounded on the semiotic analysis of discourses (from Greimas to Dondero and Fontanille), this approach includes the numerous insights of the most recent works in Communication studies. The book also offers a fruitful overview of the French tradition of critical works on cultural industries and mediations (from Barthes to Jeanneret); it also sheds light - most appropriately - on this tradition's Critical Theory background (Benjamin, Adorno \& Horkheimer, Debord). In addition, we must also highlight Mouratidou's terminological creativity. In her case studies, she proposes a range of stimulating theoretical terms, such as representation, semiotic capital, culturalisation, fictivation, event-formula, and others adopted from theatre studies.

The book opens with a robust yet stimulating theoretical introduction, settling the main conceptual frameworks and interpretative hypothesis. Its originality lies in Mouratidou's 
focus on what she calls re-presentation strategies of luxury fashion brands and their consideration as politics. The brands do not merely present products that represent them in the public sphere; they also re-present this representation to requalify the semiotic units used in the representation. This metasemiotic and reflexive process is considered as a generalized apparatus (in Foucault's sense): it tends to occupy the whole media and public space, where it conceals the very economical, ethical, and ideological nature of the market mediations.

The book is structured in three parts, which draw an analytical path from the most exposed re-presentation units to the fashion industry's deepest socio-economic machinery. In each part, thorough case studies (based upon major luxury brands such as Louis Vuitton, Dior, Gucci, Balenciaga, Chanel) alternate with more methodological, interpretative, or political considerations (about the ideological function of the fashion discourse in society).

The first two parts consider the "enunciative thickness" (épaisseur énonciative) of advertising campaigns that re-write other cultural forms and contents to link them with luxury fashion values. Fine arts, literature, religion, and politics are followed and decrypted by Mouratidou in fashion discourse. Each topic is treated through specific and always illuminating case studies, where Mouratidou shows a great talent for the detailed description of her materials and demonstrates that a semio approach requires mainly a postural work: paying attention to the details, considering every angle of a given phenomenon, immersing oneself into the semiotic experience of this phenomenon, and building, from within, the critical distance. For example, she analyzes the collaboration between Louis Vuitton and contemporary art big star Jeff Koons through its verbal and iconic dimensions, but also the specific event of the opening session in the Louvre museum, through its media coverage in the social networks, and the material dimensions of the object sac-à-main.

Hybridizations with fine arts and high culture enable fashion brands to requalify themselves as artistic instances. In doing so, they cover up the commercial nature of their relations with the clients with more legitimate values and roles. Their clients become a distinctive audience, invited to contemplate Beauty itself. On its side, the religious intertext puts the commercial instances into the scenography of worship and connects them with the Biblical narrative's sacred values (Grace, Salvation, Adoration, Holy Relic). In this chapter, Mouratidou analyses, in particular, the Kering group headquarters at the Hospice des Incurables and details the semiotic construction of both the Inaccessible and the access to the Inaccessible.

The political intertext plays an even more pervert function in fashion discourse, as it recycles, from within the capitalist system, the same forms and formulas of anti-capitalist protest. Moreover, the political quotes in fashion discourses rely on what Mouratidou calls fictivation, i.e., altering a source-text to make fictional materials out of 
non-fictional ones. From this perspective, Mouratidou analyses the 2014 Chanel fashion show, which was based on the semio-pragmatic codes of a street protest, and other discursive forms recycled from May '68 iconography, the Gilets Jaunes movement, or the feminist paradigm. In each case, Mouratidou shows how the fashion discourse erases the "social reference" and these topics' originally political meaning, using them in an iterative and confused way.

The critical perspective becomes even sharper in the third and last part of the book, which considers the fashion industry's socio-economic backstage aspects. A brief and vivid historical review explains the development, in the 1980s, of a new paradigm based on "management creativity." The concepts of panoplie (Labelle), reinvestment (Maingueneau), phantasmagoria (Benjamin, Jeanneret), and forme-loisir (Mouratidou) offer us insight into both the economic and symbolic logics of this industry. These logics have one goal, suggests Mouratidou: to redeem all the (many) dysphoric aspects of the luxury fashion's global industrialization. While the luxury industry's ecological, ethical, and socio-psychological impact has never been so dramatic, the brand consortiums (LVMH, Kering) have never been so powerful, both economically and symbolically. This power relies on the standardized politics of re-presentation: Mouratidou's critical edge culminates when she demonstrates that the most distinctive fashion sector's communication strategies are similar to prêt-à-porter.

This book is undoubtedly a must-read for everyone interested in the modern fashion industry's deep structures and surface discourses. Furthermore, its illuminating case studies show how a semio approach works in practice: refraining from theoretical dogma, Mouratidou assembles an appropriate and effective toolbox by freely drawing from critical theory, discourse analysis, communication, and mediation studies. Concerned to pay attention to the forms, she succeeds in involving the reader.

\section{References}

Adorno, Theodor W. \& Max Horkheimer 1974. La dialectique de la raison. Paris: Gallimard.

Barthes, Roland 1964. Rhétorique de l'image. Communications 4: 40-51.

Benjamin, Walter 2009. Paris, Capitale du XIXe siècle. Le livre des passages. Paris: Cerf.

Debord, Guy 1987. La société du spectacle. Paris: Gallimard.

Dondero, Maria Gulia 2009. Le sacré dans l'image photographique. Études sémiotiques. Paris: Hermès-Lavoisier.

Fontanille, Jacques 2015. Formes de vie. Liège: Presses de l'Université de Liège.

Greimas, Algirdas-Julien 2000. La mode en 1830. Essai de description du vocabulaire vestimentaire d'après les journaux de mode de l'époque. Paris: PUF. 
Jeanneret, Yves 2014. Critique de la trivialité. Les médiations dans la communication, enjeu de pouvoir. Paris: Non Standard.

Labelle, S. 2007. La ville inscrite dans la société de l'information: formes d'investissement d'un objet symbolique. PhD Thesis. Paris : Celsa - Sorbonne Université.

Maingueneau, Dominique 1991. L'analyse du discours. Introduction aux lectures de l'archive. Paris: Hachette.

\section{AUTHOR}

François Provenzano Professor of Linguistics, Rhetoric and Semiotics, Département de Langues et Littératures Romanes, Faculté de Philosophie et Lettres, U.R. Traverses, Université de Liège, Belgique. 